Cornell Law Library

Scholarship@Cornell Law: A Digital Repository

Pragmatism, Law and Governmentality

3-28-2003

\title{
Invisible Foundations: Science, Democracy, and Faith among the Pragmatists
}

Patrick J. Deneen

Princeton University, pdeneen@princeton.edu

Follow this and additional works at: http://scholarship.law.cornell.edu/ealccs_plg

Part of the Politics Commons, Religion Commons, and the Science and Technology Commons

\section{Recommended Citation}

Deneen, Patrick J., "Invisible Foundations: Science, Democracy, and Faith among the Pragmatists" (2003). Pragmatism, Law and Governmentality. Paper 2.

http://scholarship.law.cornell.edu/ealccs_plg/2 


\section{Invisible Foundations: Science, Democracy, and Faith among the Pragmatists}

Patrick J. Deneen

Princeton University

Today science is almost universally regarded as an ally of democracy. Religion once viewed by Tocqueville as the great support of democratic mores, in contrast to the materialism of then-contemporary atheists who threatened to undermine democratic commitments - is now viewed by many as antithetical to the openness and provisionality that marks both science and democracy. As framed by the neo-pragmatist Richard Rorty, religion is a "conversation-stopper," the very definition of anti-democratic, anti-scientific anti pragmatism.

In this regard, Rorty echoes the sentiments of his philosophic hero, John Dewey. Long a core feature of the pragmatist agenda, Dewey repeatedly insisted on the identification of democracy and science. For Dewey, "science, education, and the democratic cause meet as one," as he concluded in a 1944 essay entitled "Democratic Faith and Education."1 This sentiment could serve as a capstone to his lifelong belief that science and democracy were largely equivalent in "methodology" inasmuch as both were animated by a spirit of investigation, constant reconsideration and revision, and a practical orientation toward solving discrete problems. More than such methodological similarities, however, for Dewey each project was imbued with the spirit of religion, now transferred from the Churches to scientific and democratic activities. "It is the part of men," Dewey wrote in 1908, "to labor persistently and patiently for the clarification and development of the positive creed of life implicit in democracy and in science, and to 
work for the transformation of all practical instrumentalities of education till they are in harmony with these ideas." Those "habits of mind" that he saw as essential in this mutually supportive pursuit of science and democracy through education were, above all, "honesty, courage, sobriety, and faith.",

Notwithstanding Dewey's linking of science and democracy as objects of a new “common faith," religion and science are famously, or infamously, perceived as dire antagonists, locked in eternal battle for the minds and souls of believers. From antiquity - in which, as some have argued, there was a movement from muthos to logos - to Galileo's forced recantation before the Pope in 1634, to the more familiar battles of modernity such as the 1925 Scopes "monkey trial" and contemporary battles over scientific and religious pedagogy, religion and science have been posed as dire and often fatal enemies. ${ }^{3}$ Religion, based on faith, is regarded as the pure opposite of Science, which rests on skepticism, hypothesis and provisional proof.

However, it has been also long observed that science itself rests on a form of faith, a "metaphysical" foundation that pre-supposes a certain order in the universe, that presumes human intelligence to be uniquely capable of discerning that order, and that contains an implicit assumption about the inevitability of progress in knowledge and, ultimately, for humankind generally. ${ }^{4}$ Above all, if most implicitly, modern science in its earliest conception rests on the assumption that its findings will be largely benign for human beings, both in its theoretical implications and in its practical applications, resulting in the prospect and realization of the "relief of man's estate." The earliest formulations of the scientific project attest that the heavens themselves intend for mankind to pursue this theoretical and applied scientific enterprise, even if the existence 
of belief in the heavens is potentially shaken or displaced in the process, since heaven ultimately intends improvement in the human condition, liberation from drudgery, and human dominion of nature. ${ }^{5}$ Eventually, scientific faith becomes explicitly linked to democratic faith by some prominent thinkers who see a link between the ends of the two toward individual liberation, improvements to human condition that come to resemble the human intervention in accelerating evolution, and ultimately the creation of the "kingdom of God," or heaven, on earth.

Often framed in the language of myth and invoking religious imagery and theological language, early proponents of the scientific enterprise sought to reformulate the conception of the "religious" away from the Augustinian or Calvinist belief in human depravity and the irredeemable nature of earthly domain. As such, scientific proponents sought to replace such perceived pessimistic beliefs with more optimistic faith in the prospects for human and natural amelioration by means of human endeavor and investigation, and ultimately the harnessing, manipulation, improvement, and even conquest of nature. Instead of posing this new (or, for some, renewed) enterprise of scientific inquiry as antithetical to religion, many prominent thinkers promoted scientific inquiry as a form of worship, a method of inquiry that sought to divulge God's presence in the world, and ultimately as an endeavor that would yield practical benefits which themselves would permit human ascent toward the status of divinity. This enterprise was viewed as both demanded and sanctioned by God - a practice undertaken out of piety rather than apostasy. ${ }^{6}$

David Noble has persuasively demonstrated the millenarian influence in the development of this "religion of technology," beginning with the controversial abbot 
Joachim of Fiore in the thirteenth century and uncovering continuities through subsequent centuries in the thought of such figures as Roger Bacon, Giordano Bruno, Francis Bacon, Robert Boyle, the "Cambridge Platonists," Isaac Newton, and in the more secularized thought of the Freemasons, Karl Marx, and, in America, in such thinkers as Edward Bellamy. ${ }^{7}$ Noble contends that contemporary scientific projects, such as space exploration, artificial intelligence, and the rise of genetic engineering, while "masked by a secular vocabulary," are in fact actually "medieval in its origin and spirit." ${ }^{8}$ While longstanding religious doctrine held that humanity was created in the image of God and that, following Genesis, God granted humanity dominion over the earth and its creatures, following Augustinian influence these teachings did not mitigate belief in the fundamental imperfection of humanity stemming from the Fall and the primary role as "caretaker" amid nature rather than one who stood apart from nature. ${ }^{9}$ The millenarian tradition, however, departed radically from these teachings, arguing that man's fallen nature was a temporary condition and that through his own efforts he could recapture not only the state of innocence, but by means of reading and manipulating the "text" of nature itself, man could actually achieve a form of divinity. A representative statement is articulated by Giordano Bruno at the end of the sixteenth-century, who stated that such effort, in copying the creative activities of God, is sanctioned and ordained by God: Providence has decreed that man should be occupied in action by the hands and in contemplation by the intellect, but in such a way that he may not contemplate without action or work without contemplation. [And thus] through emulation of the actions of God and under the direction of spiritual impulse [men] sharpened their wits, invented industries and 
discovered art. And always, from day to day, by force of necessity, from the depths of the human mind rose new and wonderful inventions. By this means, separating themselves more and more from their animal natures by their busy and zealous employment, they climbed nearer the divine being. ${ }^{10}$

The millenarian and proto-scientific tradition - one that increasingly understood human activity as itself the necessary component to bring about the kingdom of God on earth - repeatedly emphasized three beliefs that constitute the "religion of technology": first, the belief in progress; second, the ideal of human self-transformation; and third, the aspiration of human ascension to godliness. Each of these ends was to be achieved by means of mastery of "natural philosophy," the forerunner of science. If the story of the Fall had previously been understood to define strict limits on human aspirations and to deny the possibility of human perfectibility, millenarian interpretations increasingly understood the story of Adam's transgression to portray a temporary condition of ignorance that could be reversed by means of the development of human knowledge and applications of inventions and discoveries. ${ }^{11}$ Progress was thus, in effect, a process of "rediscovery" of what mankind had lost at its point of origin, but this second time not as an unearned gift from God's hand, but a divinely sanctioned result of human inquiry into God's creation. Reflecting this renewed confidence in human perfectibility was John Milton, who surmised that "when the cycle of universal knowledge has been completed, still the spirit will be restless in our dark imprisonment here, and it will rove about until the bounds of creation itself no longer limit the divine magnificence of its quest.... Truly [man] will seem to have the stars under his control and dominion, land and sea at his 
command, and the winds and storms submissive to his will. Mother Nature herself has surrendered to him. It is as if some god had abdicated the government of the world and committed its justice, laws, and administration to him as ruler."12

Among the earliest and most celebrated calls for the prospects of near-infinite human self-improvement was Pico della Mirandola’s 1486 “Oration on the Dignity of Man" which evinces this tripartite belief in progress, self-transformation and the possibility of humanity ascending to divinity by means of science. Evoking a version of the Prometheus myth as purportedly related by Protagoras in Plato's dialogue Protagoras, Pico at once "updates" the ancient tale for a Christian audience and transforms the Biblical story of creation as told in Genesis into one in which human beings avoid the Fall and further become defined by a very absence of fixed properties. God creates humankind as an afterthought, having fashioned all of existence but without any creature that could "ponder the plan of so great a work, to love its beauty, and to wonder at its vastness."13 Since He had not initially planned to create mankind, God has already exhausted all of the "archetypes" and there exists no model remaining in his "treasure-houses" upon which to base this new creature. "All was now complete; all things had been assigned to the highest, the middle, and the lowest orders."14

While Pico's portrayal of Divine oversight and limitation here runs the risk of blasphemy, he moves to affirm God's limitless powers of creation by describing the fashioning of a creature without fixed qualities or talents:

He therefore took man as a creature of indeterminate nature and, assigning him a place in the middle of the world, addressed him thus: "Neither fixed abode nor a form that is thine alone nor any function peculiar to thyself 
have we given the, Adam, to the end that according to thy longing and according to thy judgment thou mayest have and possess what abode and what functions thou thyself desire. The nature of all other beings is limited and constrained within the bounds of laws prescribed by Us. Thou, constrained by no limits, in accordance with thine own free will, in whose hand We have placed thee, shalt ordain for thyself the limits of thy nature. We have set thee at the world's center that thou mayest from thence more easily observe whatever is in the world. We have made thee neither of heaven nor of earth, neither mortal nor immortal, so that with freedom of choice and with honor, as though the maker and molder of thyself, thou mayest fashion thyself in whatever shape thou shalt prefer. Thou shalt have the power to degenerate into the lower forms of life, which are brutish. Thou shalt have the power, out of thy soul's judgment, to be reborn into the higher forms, which are divine. ${ }^{15}$

Because of this unique and singular origin and destiny, humans exist at a "rank to be envied not only by brutes but even by the stars and by minds beyond this world."16 Combined with his portrayal of God as limited to creating based on pre-existing "archetypes" to which He cannot add (thus having only recourse to the fashioning of humans without qualities), this conception of humanity as entirely self-creating hints at a curious displacement and reversal of the divine and the human: God "creates" humanity to be self-creating, even "self-transforming," potentially growing into "a heavenly being" (if rational), "an angel and the son of God" (if intellectual), or one that "made one with God ... shall surpass them all (if withdrawn "into the center of his own unity")."17 God is 
constrained in his creation of humanity by the prior existence of uncreated "archetypes," indicating a curiously limited deity who nevertheless negotiates these limits by means of the creation of a creature that does not appear, in the end, to be so limited. If God's limits force him to create mankind as a creature without qualities, humanity in turn becomes a creature who creates, one that can even make itself into a divine being - something that God could not do, since the divine is itself uncreated, whereas humans are not limited to those same prior "archetypes."

While the necessity and these powers of self-creation come initially from God, they can only be exercised and realized by humans. God intends for human beings to make as much of themselves as they can - even to the point of transforming themselves into divine beings. Thus, God sanctions and blesses human attempts at self-perfection. Pico makes this clear in his call for humanity to embrace "natural philosophy," the philosophical investigation of natural phenomenon. Despite leaving mankind without qualities, God gives to humanity the script by means which it can avoid a descent into depravity and instead attain a divine condition. Distinguishing a laudable form of "magic" from a form of deceptive conjuring (Pico praises the magus who is "the servant of nature and not a contriver"18), he describes how the magus can become "ruler and lord" by "calling forth into the light as if from their hiding-places the powers scattered and sown in the world by the loving-kindness of God," and thus "does not so much work wonders as diligently serve a wonder-working nature." This investigator "brings forth into the open the miracles concealed in the recesses of the world, in the depths of nature, and in the storehouses and the mysteries of God, just as if she herself were their maker; 
and, as the farmer weds the elms to vines, even does the magus wed earth to heaven, that is, he weds lower things to the endowments and powers of higher things."19

This knowledge is not, however, the result of superficial investigation into the natural world. Rather, by undertaking to discern God's mysteries hidden throughout the earth and the heavens, finally to "wed earth to heaven," mankind ascends to a godlike status.

Once we have achieved this by the art of discourse and reasoning, then, inspired by the Cherubic spirit, using philosophy through the steps of the ladder, that is, of nature, and penetrating all things from center to center, we shall descend, with titanic force rending the unity like Osiris into many parts, and we shall sometimes ascend, with the force of Phoebus collecting the parts like the limbs of Osiris into a unity, until, resting at last in the bosom of the Father who is above the ladder, we shall be made perfect with the felicity of theology. ${ }^{20}$

Human perfectibility is within its own power, achieved by means of "reading" and interpreting the text of nature wherein lie hidden God's hints of how to achieve a kind of divinity. If "theology" is needed to achieve final perfection, Pico suggests throughout that the most pious form of inquiry - the one intended by God at the time of humanity's creation - is the effort to understand divine intention through the scientific investigation of nature.

Pico's emphasis on God's hidden mysteries and the role of humanity in exposing and exploiting those clues is echoed in Francis Bacon's frequent invocation of Proverbs 25:2, "It is the glory of God to conceal a thing: but the honor of kings to search out the 
matter." 21 While Bacon's work is often cited for its influence in the modern belief in progress - especially the progress achieved by means of a scientific enterprise dedicated to the "benefit and use of men" - less often perceived are Bacon's accompanying belief in the possibility of human transformation by means of scientific advancement, and ultimately the prospect of him "similitude" to the status of the Divine. ${ }^{22}$ If Bacon is regarded as the progenitor of the secular modern scientific project, it is no less true that he perceived that project's secular aims to be wholly in keeping with divine strictures and ultimately undertaken under divine sanction and with an end to the greater glory of God and the ultimate deification of humanity.

Echoing the belief of many millenarians, Bacon rejected the suggestion that mankind's fall from Eden indicated that human inquiry was forbidden or discouraged, but in a spirit of piety concluded that such inquiry should not be undertaken as an effort to displace God. Bacon distinguished between rightful form of human dominion in the earthly realm and the illegitimate attempt by mankind to free itself altogether from God's commandments. ${ }^{23}$ Inquiry is to be limited by this outer boundary, to be undertaken at all times with piety and obeisance to divine majesty. Thus, Bacon writes, "all knowledge is to be limited by religion....,24

Yet these strictures are not as limiting as they might first appear. In Valerius Terminus or "Of the Interpretation of Nature" - an early fragmentary work, believed to have been written in 1603 in preparation for The Advancement of Learning - Bacon argued that mankind in Eden, like the rebelling angels, had sought to "ascend and be like unto the Highest," and instructively adds, "not God, but the highest." ${ }^{25}$ The transgression of Lucifer and the angels, like the transgression of Adam and Eve in the garden of Eden, 
was to seek to become higher than God rather than seeking to be like God. While the attempt to gain "knowledge of good and evil" intruded into "God's secrets and mysteries," Adam's dominion over nature before the Fall - indicated especially by his naming of the animals - revealed that inquiry and knowledge was the proper provenance of prelapsarian humankind. ${ }^{26}$ Bacon concludes that, "as to the goodness of God, there is no danger in contending or advancing towards a similitude thereof, as that which is open and propounded to our imitation.,"27

The "limitation" demanded by religion on scientific inquiry is revealed essentially to present no limitation at all. Piety requires thorough human investigation and harnessing of all natural phenomena: "For that nothing parcel of the world is denied to man's inquiry and invention...."28 "Heaven and earth do conspire and contribute to the use and benefit of man," Bacon insisted, pointing to a confluence of sacred and secular grounds for the pursuit of knowledge. ${ }^{29}$ Divine scripture "invite[s] us to consider and to magnify the great and wonderful works of God," an acknowledgement which leads Bacon to admonish his readers that "religion should dearly protect all increase of natural knowledge., 30

By means of properly pursuing the advancement of learning - not in the manner of Adam in precipitating the Fall by seeking the knowledge of good and evil, but rather in the manner of Adam prior to the Fall - mankind could hope to reverse the consequences of the Fall. Through investigation and artifice mankind could re-achieve what was once its divine inheritance, and by means of inquiry it might restore the prelapsarian condition of plenitude, ease, peace, and even immortality. ${ }^{31}$ The pursuit of this rightful form of inquiry could be expected to lead to 
a restitution and reinvesting (in great part) of man to the sovereignty and power (for whensoever he shall be able to call the creatures by their true names he shall again command them) which he had in his first state of creation. And to speak plainly and clearly, it is a discovery of all operations and possibilities of operations from immortality (if it were possible) to the meanest mechanical practice. ${ }^{32}$

Beyond those desirable if still "vulgar" ends of knowledge - which include "imperial and military virtue" as well as "power and commandment" over other humans - is the most sublime and final end of knowledge: by means of learning, "man ascendeth to the heavens" and achieves that to which "man's nature doth most aspire, which is immortality or continuance."33

Bacon unveils his confidence in human mastery of the universe, even beyond that of God, perhaps most suggestively, if subtly, in his re-telling and interpretation of the myth of Prometheus in The Wisdom of the Ancients. Deploying the same tactic as Protagoras and Pico della Mirandola before him, and Percy Bysshe Shelley after him, the Promethean myth provides fertile ground in which to "rediscover" mankind's powers and restore human optimism of its central place in the natural and even divine order. While retaining enough elements of the tale to appear faithful to the original myth, Bacon in fact alters several familiar elements in order to permit an interpretation that is most sympathetic to mankind's capacity and points to the possibility of human transformation and even exhaltation over the divine.

"Prometheus, or the State of Man (Explained of an overruling Providence, and of Human Nature)" is the longest of Bacon's thirty-one retellings of classic myths in The 
Wisdom of the Ancients. Bacon had cause to wish to call attention to the essay, for it is a subtly crafted exposition of humanity's place in the natural and divine order, and further, an exhortation for humanity to improve its position within that order (thus, to that extent, it resembles in more than subject matter Pico's "Oration"). As in the versions by Protagoras and Pico, Bacon relates that Prometheus created humanity and at some point he stole fire from the gods and gave it to humanity. At this point, however, Bacon departs from known versions of the myth: mankind responds to this gift with ingratitude, and arranges for Prometheus to be tried by Jupiter. Curiously, Jupiter is delighted with humanity's efforts to prosecute Prometheus and by their possession of fire, and extends to them perpetual youth. Humanity foolishly gives away the latter gift to an ass, who then subsequently gives it to the race of serpents. Nevertheless (according to Bacon), Prometheus continues his "unwarrantable practices" (rather than, as the classic myth had it, protecting humanity) by deceiving Jupiter into choosing an unworthy sacrifice, and for his deception he provokes Jupiter to fashion a punishment against humanity in the form of Pandora and a box of curses. Prometheus is also bound in chains to the side of a mountain where a vulture daily consumes his liver, and is released from this punishment only when Hercules sails by upon the ocean, shoots the bird and sets Prometheus free. ${ }^{34}$

In his explanation, Bacon varies his account of the symbolic meaning of Prometheus, but at the outset he states that "Prometheus clearly and expressly signifies Providence." 35 By "providence" Bacon seems to suggest that Prometheus symbolizes mankind's divinely-ordained destiny, the repository of God's plans for the universe (thus, he writes, "providence is implanted in the human mind in conformity with, and by the direction and the design of the greater overruling Providence" ${ }^{36}$ ). The "principal" ground 
for understanding Prometheus to signify Providence is because "man seems to be the thing in which the whole world centers, with respect to final causes" as explained at length by Bacon:

So that if he [i.e.,mankind] were away, all other things would stray and fluctuate, without end or intention, or become perfectly disjointed, and out of frame; for all things are made subservient to man, and he receives use and benefit from them all. Thus the revolutions, places, and periods, of the celestial bodies, serve him for distinguishing times and seasons, and for dividing the world into different regions; the meteors afford him prognostications of the weather; the winds sail our ships, drive our mills, and move our machines; and the vegetables and animals of all kinds either afford us matter for houses and habitations, clothing, food, physic; or tend to ease, or delight, to support, or to refresh us so that everything in nature seems not made for itself, but for man. ${ }^{37}$

Prometheus, qua Providence, would appear to be a worthy object of human gratitude and praise for this bounty of natural provisions and human dominion, but Bacon here surprises with his interpretation of his own departure from the traditional tale, in which, as Bacon relates, Prometheus receives instead ingratitude from humanity for his gifts. Calling it "a remarkable part of the fable" (which, clearly, it is, inasmuch as Bacon himself fashioned it), he recognizes that "it may seem strange that the sin of ingratitude to a creator and benefactor, a sin so heinous as to include almost all others, should meet with approbation and reward. ${ }^{38}$ However, Bacon asserts that the fable teaches its perceptive readers that such ingratitude "proceeds from a most noble and laudable temper 
of the mind," namely that those "who arraign and accuse both nature and art, and are always full of complaints against them ... are perpetually stirred up to fresh industry and new discoveries. ${ }^{\circ 9}$ By contrast, those who stand in awe of humanity's place in the universe - and express gratitude for this position - are in fact subject to think themselves satisfied with their current state, and "rest, without further inquiry." This latter condition, Bacon avers, shows "little regard to the divine nature." 40

In his interpretation of the preceding passage, Bacon subtly shifts the ground from his initial identification of Prometheus with "Providence" that directs mankind - a providence that affords men "mind and understanding" providence is itself subject to a strenuous and accusatory form of human inquiry that it afforded in the first instance. Ingratitude only appears at first glance to be a sin: in fact, ingratitude - whether to "a creator and benefactor" (which only appears "heinous"), or to "nature and art" (which is praiseworthy) - in both cases is curiously sanctioned and ultimately rewarded by “the divine nature." Echoing Pico's treatment, Bacon suggests that humanity is providentially given the necessary tools by which to "arraign and accuse" Providence, and can expect to be rewarded for these exertions by a higher power - even to receive the gift of immortality. Humanity has only unsuccessfully pursued the possibility of immortality due to impatience and unnecessary abstraction, but it is now within its reach - having now the example of the ancients both to emulate and to improve upon - to become, like the patient ass, "a useful bearer of a new and accumulated divine bounty to mankind." 42

As if to constrain the impious implications of his analysis, Bacon concludes with an interpretation of that section of the myth in which punishment is inflicted daily upon 
Prometheus by an eagle, suggesting that this image affords a warning against overweening and impious inquiries. "The meaning seems to be this," Bacon writes, "that when men are puffed up with arts and knowledge, they often try to subdue even the divine wisdom and bring it under the dominion of sense and reason, whence inevitably follows a perpetual and restless rending and tearing of the mind. A sober and humble distinction must, therefore, be made betwixt divine and human things, and betwixt the oracles of sense and faith...."43 Almost unnoticeably, Bacon has replaced his initial interpretation identifying Prometheus with "Providence" with one that identifies Prometheus with humanity. Yet, it is a subtle transformation that has in fact been effected by means of the preceding "explanation" of the need to use the gifts of providence to interrogate providence, and effectively make one's own new kind of "providence" by means of those gifts. If humanity, in effect, makes itself into its own providential agent, then it now stands no longer at odds with Prometheus, but instead against Zeus - the implied "higher power" that stands even above Providence. Bacon's warning seems to be, lest we tempt the kind of punishment visited upon Prometheus by Zeus - that daily "rending and tearing" - we must humbly acknowledge the distinction between "divine and human things."

That might conclude matters but for the highly curious interpretive passage that has preceded this explanation of Prometheus' punishment which, in the original fable related by Bacon, in fact follows the description of the Prometheus' daily torture. Bacon interprets the freeing of Prometheus before his interpretation of the punishment. ${ }^{44}$ Thus, though his explanation precedes this apparently final warning about the need for human piety, in fact the prior interpretation of Hercules' role in Prometheus' liberation is the 
"final" lesson of the allegory in spite of its penultimate placement in the interpretation. As for the role of Hercules, Bacon writes

even Prometheus had not the power to free himself, but owed his deliverance to another; for no natural inbred force and fortitude could prove equal to such a task. The power of releasing him came from the utmost confines of the ocean, and from the sun; that is, from Apollo, or knowledge.... Accordingly, Virgil ... account[s] him happy who knows the cause of things, and has conquered all his fears, apprehensions, and superstitions. $^{45}$

Curiously, Prometheus - who had provided humanity with the capacity to forge his own inquiries, even to the point of "arraigning" Prometheus, or "Providence" - does not now possess the abilities to free himself. He has not conquered all of his fears - fears that he has not hitherto evinced in his willingness to combat Zeus - suggesting that his final fear is his unwillingness to possess the power that would forestall his punishment (or superstitious fear of punishment) and make his liberation at the hands of another unnecessary. Hercules represents the fearless scientist or discoverer - he who "supports and confirms the human mind" - who finally liberates the now humanized Prometheus from his final "fears, apprehensions and superstitions." The prospect of liberation at the hands of Hercules makes the fear of Zeus superfluous and apprehension of punishment nugatory, since, by emulating Hercules, humanity has no fear of any external form of bondage given that it possesses of all the means of self-liberation. The final statement on the significance of Hercules - and hence, of the parable itself - confirms that human transformation and ascendance to the status of human divinity is the true object of 
Bacon's teaching: "as if, through the narrowness of our nature, or too great a fragility thereof, we were absolutely incapable of that fortitude and constancy to which Seneca finely alludes, when he says: 'It is a noble thing, at once to participate in the frailty of man and the security of a god.",46 Bacon sought to remake humanity, by means of the advancement of learning and its resulting aim at "the glory of the Creator and the relief of man's estate," allowing humanity to achieve their due status, "not animals on their hind legs, but mortal gods."47

Bacon may be a curious and objectionable imputed background source for the eventual identification between advances in science and democracy, especially given that Bacon was a committed monarchist and frequently recommended secrecy in political matters. ${ }^{48}$ Yet Bacon advances arguments on behalf of the scientific enterprise that are easily assimilated to democratic ends, and indeed, may even lead logically and necessarily in that direction - a trajectory of which Bacon, in several moments, appeared himself to be well aware.

There is, of course, a potential tension between the scientific enterprise which emphasizes the role of expertise and elite knowledge, and democracy's expectation of the basic competence among, and widespread participation of, the citizenry. Even the most fervent democrats have recognized that informed elites play a role in the cultivation of intelligence and judgment among the populace. John Dewey, for example, readily recognized that "for most men, save the scientific workers, science is a mystery in the hands of initiates.... ${ }^{49}$ Modern democracy requires sufficient knowledge of complex issues, requiring not only the means of communication that adequately disseminate information and knowledge, but adequately developed individual understanding of 
methods of inquiry and analysis. For Dewey, modern America had successfully achieved the former, but was woefully insufficient in development of the latter. Answering Walter Lippmann's questioning of the political competency of the ordinary person, Dewey called for the "artful" presentation of the latest advances in scientific inquiry, likening the successful dissemination of knowledge of "enormous and widespread human bearing" to enticing forms of literary presentation. By means of such artistically rendered knowledge, Dewey believed that the creation of a "Great Community" was possible, one composed of "an organized, articulate Public." Here Dewey acknowledges the central role not of a scientist or inventor, but to democracy's "seer," Walt Whitman. He concluded that democracy would achieve a consummation when "free social inquiry is indissolubly wedded to the art of full and moving communication.",50

In both these respects Bacon anticipates this "wedding" of scientific inquiry and democracy, particularly by linking the method of scientific inquiry to the concomitant amelioration of the human condition, brought about by the resultant practical applications and devices that would expand opportunities for leisure and universal communication. In several instances Bacon emphasized how his recommended form of scientific inquiry is based upon, and substantively promotes, a kind of equality. Denying that the scientific enterprise calls for a kind of specialized and elite knowledge, in the Novum Organum Bacon asserted that the form of inquiry he recommended was universally accessible: My method of scientific discovery leaves only a small role to sharpness and power of wits, but puts all wits and understandings more or less on a level. For just as drawing a straight line or a perfect circle simply by hand 
calls for a very steady and practiced hand, but little or no skill if a ruler or pair of compasses is used, so it is with my method. ${ }^{51}$

Bacon thus suggested that his method advances two forms of equality - one that is intrinsic to the method itself ("puts all wits and understandings more or less on a level"), and the other that is the result of practical applications deriving from the successful inquiry into natural causes ("little or no skill [is required] if a ruler or pair of compasses is used").

Bacon was keenly aware of the egalitarian, and even democratic, implications of the methodology itself. As he stated early in his writings, "howsoever governments have several forms, sometimes one governing, sometimes few, sometimes the multitude; yet the state of knowledge is ever a Democratie, and that prevaileth which is most agreeable to the senses and conceits of the people." 52 In seeking to employ the method of scientific inquiry - one that "puts all wits and understandings more or less on a level" - the expected result is the discovery of new applications that lighten the burdens of humanity, increase longevity, and promote social intercourse between citizens and people of varying nations. Writing in theNew Atlantis about the final aim of the "Salomon's House," or "The College of Six Days," Bacon wrote that "the End of our Foundation is the knowledge of Causes, and the secret motions of things; and the enlarging of the bounds of Human Empire, to the effecting of all things possible." 53 The discovery of "secret motions" and subsequent inventions that improve upon nature's bounty allows for the increased likelihood of practical human equality - such as the universal capacity offered by the "compass," when previously only a skilled hand could draw a perfect circle. Both the method of scientific inquiry, and its resultant applications, point to a democratic 
trajectory that was perceived even by Bacon, and became readily apparent to full-blown democratic faithful.

Dewey, for instance, spared no praise for Bacon, calling him "the forerunner of the spirit of modern life," the "real founder of modern thought," and "the prophet of a pragmatic conception of knowledge." ${ }^{, 54}$ In particular Dewey praised three aspects of Bacon's practical philosophy: first, his insistence that "knowledge is power," or that true knowledge leads to human empowerment over natural phenomena; second, his "sense of progress as the aim and test of genuine knowledge," the continual amelioration of the human condition by means of unceasing investigation and interrogation of nature; and third, his insight that led to the perfection of the inductive method of experimentation, one that stressed activity and the constant "invasion of the unknown" based on the rejection of certainty and the embrace of ever-constant doubt. ${ }^{55}$ In The Public and Its Problems, Dewey articulated how this approach to human knowledge - one that aimed at practical amelioration of conditions as well as expanding circles of knowledge throughout the citizenry - was the essence of democratic life. Beyond mere suffrage or distant oversight over the activity of its representatives, active and universal inquiry and amelioration was the basis of a true democracy. In this sense, Dewey averred, "the cure for the ailments of democracy is more democracy." 56 If Bacon did not see the full implications of his own analysis, never "discovered the land of promise," Dewey insists that "he proclaimed the new goal and by faith he descried its features from afar."57

One sees the final aim of Baconian science in its original conception - namely, the transformation of humanity - continue to be articulated among proponents of democracy, but often in less overtly religious tones as those employed by Bacon. Indeed, 
ironically, due to the intervening history in which religion has been perceived to be more hostile than friendly toward the scientific enterprise, defenders of the scientific faith have advanced claims to human transformation as a prospect in spite of, and antithetical to, traditional religious belief. ${ }^{58}$ Richard Rorty captures the dual religious and anti-religious sense of this belief in the transformative powers of humanity by means of the interlinking of science - as the means of "relieving the human estate" - and democracy:

In past ages of the world, things were so bad that "a reason to believe, a way of to take the world by the throat" was hard to get except by looking to a power not ourselves. In those days, there was little choice but to sacrifice the intellect in order to grasp hold of the premises of practical syllogisms - premises concerning the after-death consequences of baptism, pilgrimage or participation in holy wars. To be imaginative and to be religious, in those dark times, came to almost the same thing - for this world was too wretched to lift up the heart. But things are different now, because of human beings' gradual success in making their lives, and their world, less wretched. Nonreligious forms of romance have flourished - if only in those lucky parts of the world where wealth, leisure, literacy, and democracy have worked together to prolong our lives and fill our libraries. 59

For Rorty, the opportunities afforded by these contemporary advances - ones that he frequently and gratefully attributes to Bacon's proto-pragmatic arguments in favor of "knowledge as power" 60 - allow now for us to be "carried beyond presently used 
language. ${ }^{61}$ Humanity transforms itself by means of new uses and employment of language, according to Rorty's admonition of "liberal irony.",62

For all the confidence in the prospect of democratic consummation and human transformation afforded by the modern scientific enterprise as expressed by such optimistic thinkers as Dewey and Rorty, there has persisted the misgiving that the scientific project may not be as seamlessly supportive of democracy's aims as might be hoped by the most faithful devotees. One only needs consider those social scientists of the early twentieth-century - such as 1934's A.P.S.A. President Walter Shepard, whose scientific conclusions prompted him to call for a thorough reconsideration and revision of the prevailing "democratic faith" - to perceive the source of continued misgivings about the relationship between the scientific enterprise and democracy. To the extent that each rests on a kind of faith in a better future, however, it is not surprising to find testaments of faith that endorse, promote, and even proselytize on behalf of a strengthened faith in the shared aims of science and democracy. ${ }^{63}$

One noteworthy document that affirms a firm connection between democracy and the ends of science (as against the more suspect forms of religious faith) is the Proceedings of a conference held in New York City in May, 1943, entitled The Scientific Spirit and Democratic Faith. ${ }^{64}$ Organized in part to combat the threat posed by the “closed society" of fascism, as well as to repudiate perceived authoritarian leanings of religious organizations within liberal democratic societies, the conference gathered together both prominent democratic theorists - such as Horace M. Kallen - as well as practicing scientists of different stripes, all with a common ambition to argue on behalf of "an essential interrelation" between science and democracy. ${ }^{65}$ Most remarkable about the 
document is the extent to which the tension that the conference sought implicitly to dispel - the fear that the scientific project and democracy may not be altogether compatible enterprises - was in fact deepened by a curious disconnection between the vision of the conference's democratic theorists and its scientists. One might suspect that the conference's participants became anxious as the conference unfolded; yet, amid the shared optimism over the strong linkage of science and democracy, there was an absence of reflection upon the implications of the proceedings, and no self-conscious notes of caution during the conference.

Infused with the spirit of pragmatism - one of the organizers explicitly states that the participants were "radical democrats" in the spirit of Emerson and belonged to the American philosophic tradition of William James and John Dewey - the papers of the first half of the volume strongly assert the essential connection between the freedom of inquiry required by science and the condition of open and ranging freedom that defines democratic politics at large. ${ }^{66}$ Echoing Dewey, as well as the more distant echoes that Dewey attributed to Bacon, the organizers set forth several guiding principles of the conference, including the following:

- The scientific spirit is in essence the modern search for truth;

- The democratic faith is in essence the belief that human resources may become adequate for human needs wherever freedom of inquiry exists and cooperative techniques are developed

- The scientific spirit is dependent upon the democratic faith in the sense that science cannot develop into an instrument for human welfare except in an atmosphere of freedom. ${ }^{67}$ 
Science requires democracy in order to fully engage in the search for truth without obstruction from authoritarian sources; democracy requires science to the extent that citizens must be afforded every opportunity for material advancement, as well as equipped with the tools of discernment provided by scientific inquiry, ultimately with an aim to making them capable of thinking and interacting by employing the same methodological approach as scientists. Thus, another principle affirmed by the conference holds that "when the democratic faith becomes practice the resulting process is one in which all policy-making is an affair of participation. Policies which need to be 'lived out,' decisions which seek to represent the experience of the people, must be derived from the participating knowledge and experience of the people., 68

Horace M. Kallen echoes these principles in his spirited attack on authoritarianism and a defense of the scientific enterprise and its essential connection to the democratic faith. Like democracy, science thrives on free inquiry and implies the equality of all reasonable participants:

The sciences are preeminently the fields of free thought. No idea, no hypothesis, no technique that they consider is admitted to a privileged status. None is exempt from the competition of alternatives. None is denied the cooperation of its competitors in the tests of its validity. None enters the field as a truth revealed, self-evident, beyond the challenge of doubt, beyond the proofs of inquiry. ${ }^{69}$

For Kallen, as for Dewey, the phrases "scientific spirit" and "democratic faith" overlap to the point of being indistinguishable: both "convey an identical attitude in different but interacting undertakings of the human enterprise. ${ }^{, 70}$ From the anti-foundational, 
pragmatic point of view, all certainties - whether in natural sciences or politics - are in fact merely apparent, and must be subject to revision and potential rejection by unceasing inquiry and investigation. All beliefs are provisional, and "faiths" that maintain certainties are to be exposed and dismissed as forms of "spiritual fascism."," Kallen's certainty on the progressive nature of uncertainty derives from his democratic faith, the belief that open inquiry in the political and scientific realms will be forever mutually supportive in improving humanity's condition, and that all democratic citizens can be brought to a level of sufficient sophistication and interest to employ the methods of science in their own formulations of public policy.

This belief was fully shared by the practicing scientists who participated in the conference, several of whom strongly endorsed this "democratic faith" and who viewed the full flourishing of science as affording the opportunity to move humanity to a condition that would justify this initial faith in their universal capacities. One scientist Alfred Mirsky, an Associate Member of the Rockefeller Institute for Medical Research distinguished between "those people who do not have the democratic faith" and thus who shared "a very low opinion of human nature" (here quoting, as an example, Alexander Hamilton), and those people "who do have the democratic faith" made possible by a "more optimistic point of view towards human nature.",72

To demonstrate that this more "optimistic" faith in humanity is warranted, Mirsky launched into a lengthy analogy drawn from his close experience with laboratory rats. He noted that rats which are ill-treated - kept in dirty cages and not fed or handled sufficiently - are wild and uncontrollable. By contrast, those rats that are kept clean and well-fed are mild and gentle. "Petting" and encouraging laboratory rats become 
accustomed to their "caretakers" is essential in this process of "gentling.,"73 To further demonstrate his point, he described that ill-treated rats died with high frequency with the removal of the parathyroid gland, whereas "gentled" rats survived the operation at a much higher rates. Mirsky concluded that this comparison revealed the central importance of conditioning and pointed to its promise in the realm of genetic experimentation. In his peroration, he drew an explicit comparison between the more docile manner and better physical health of well-treated rats to human beings, calling for humans to be treated in a similar manner: "I think we know enough to say that if man were treated the way these rats have been in the laboratory, then ... there are good grounds for the democratic faith; in other words, for the faith that there are some good potentialities in ordinary human beings." ${ }^{, 74}$ While one can hardly gainsay the benefits of greater health - particularly necessary for laboratory animals in order to survive experimental surgery (a point which gives pause when Mirsky opines that "man should be studied in laboratories much more than he is") - one wonders if "gentling" is the highest democratic virtue that science can offer to humanity, and whether those purported "democratic" virtues of unceasing inquiry and participation - emphasized in the volume by Kallen - are aided by the experimental support of "responsible" scientists who count themselves among the democratic faithful.

Mirsky's vision of science that provides the means of transforming humans into more suitable democratic citizens is not a curious exception among the scientific participants at the conference, but a view shared by several others (all specially selected for the occasion), including Richard M. Brickner, an Associate Professor of Clinical Neurology at the College of Physicians and Surgeons. Brickner described his discovery 
as a practicing psychoanalyst that numerous apparently "normal" patients have extraordinarily "primitive" qualities, including "death wishes and hatreds and urges to aggression." ${ }^{75}$ Psychotherapy brings these hidden pathologies to light, and, while Brickner did not contend that these aggressions can be alleviated, he argued that the awareness of their existence thereby alerts people to the imperative to avoid acting upon them. Echoing the sentiments of Albert Mirsky, Brickner stated that "it does seem to clear things up to know what is bothering you is that you are the same as a lion or a dog or an ungentleable rat in some ways." He concluded: "People get better, they get happier, when they have been through such a course of education.,"76

Again echoing Mirsky, Brickner argued that responsible scientists can offer their expertise to improve democratic conditions. Specifically, Brickner proposed to prevent the onset of adolescent disillusionment by forestalling the initial implantation of illusions in young children. He insisted that he and other scientists should "teach some of the principles we find useful in adult psychotherapy to children as a sort of prophylactic psychotherapy.",77 As Mirsky suggested, wild rats cannot be easily "gentled," but laboratory rats, bred in captivity, and treated properly, can be conditioned to be gentle if one begins from the point of birth. Similarly, "wild" humans can only with difficulty be "gentled" by means of extensive psychiatric intervention; better to avoid this eventuality by beginning gentling treatment from a very young age. As Mirsky argued, "genetically, [the gentled rat] is quite a different animal. His inherent germ-plasm or whatever you care to call it is different from that of the [wild] rats, and it really is impossible to gentle his variety of rat." 78 
These proposed "democratic" applications of science appear to be a long way from Bacon's belief that science allowed the realization of the proud declaration that humans are "not animals on their hind legs, but mortal gods." Yet, if these expressions of democratic science appear to reduce humanity to the level of "mere" animals laboratory rats - its aim is ultimately consistent with Bacon's belief that purely material amelioration, by means of inquiry into purely natural phenomenon, was the route to a new form of divination (after all, Mirsky and Brickner each speak of the "gentled" rat as a signal improvement over its naturally "wild" alternative, and Mirsky points to the possibility of genetic improvement of the species). The linkage of this aim to a rarified democratic faith makes explicit the attempt to universalize this outcome for all citizens, to make common the transformation of imperfect creatures into - in Rorty's words - "a more evolved form of humanity," made possible by the "principle means" of democracy. ${ }^{79}$

\section{Perilous Faith}

Such thinkers are both keenly aware of the dangers of "faith," on the one hand particularly a religious faith - and, on the other hand, the political pitfalls of faithlessness. Faith is both dangerously absolutist in the one guise (especially religious faith), and regarded as a requirement in order to maintain belief in a fully democratic future (a "democratic faith"). The "democratic faithful," however, are strikingly unwilling to consider the potential dangers of their own "absolutism" even as they exhibit fierce suspicion about any other "absolutist" claims, especially any forms of "absolutist" faith 
in the divine that may, in fact, offer more resources for the resistance of hubris and the possibility of true humility than that "democratic faith" which they embrace.

Particularly because of "progressivist" assumptions that underlie pragmatic belief in the "democratic faith" - assumptions about the positive results of technological developments that are understood to increase human possibilities of communication and "intelligence," ranging from Dewey's faith in the promise of the locomotive and telegraph to Benjamin R. Barber's faith in the promise of the incipient internet - the "democratic faithful" are often keenly unaware of "unintended consequences" that may, and often do, accompany these "developments." ${ }^{\text {" S0 }}$ Such "unintended consequences" may undermine what are arguably necessary features of democracy (such as the civic trust that may be undermined as a result of the "advances" in transportation and communication, an effect often attributed to the anomic lifestyle that has resulted from an automobile and internet culture), or may neglect the necessary conditions of a decent human life lived in concert, rather than in competition, with nature.

One sees evidence of such overconfidence in the methodology of science throughout Dewey's work. Noting his indebtedness to Francis Bacon, Dewey wrote that "scientific laws do not lie on the surface of nature. They are hidden, and must be wrested from nature by an active and elaborate technique of inquiry." ${ }^{, 11}$ The job of the modern, and especially modern science - a realm of inquiry that extends to the human sciences (such as political science) as well as to the natural sciences - is to extract the secrets of nature by whatever means possible, even if these methods at times evoke ominous overtones and disturbing consequences. Again echoing Bacon, Dewey revealed the severity with which the modern scientist must approach his task: 
[he] must force the apparent facts of nature into forms different to those in which they familiarly present themselves; and thus make them tell the truth about themselves, as torture may compel an unwilling witness to reveal what he has been concealing. ${ }^{82}$

Because technology is seen as wholly in the service of democratic ends, one often sees in Dewey's work a blithe unwillingness to acknowledge the ways technologies may in fact serve ends that are, in the first instance, anti-democratic, and beyond, hostile to human and natural ecology. It is at least curious that Dewey should have put so much faith in the compatibility of scientific progress and democracy - having lived through decades in which American social science demonstrated how "science" could be rendered altogether hostile to democratic "faith" - and finally ironic inasmuch as it would be Dewey's own faith to which the social scientists would appeal as a way of limiting the implications of their science. $^{83}$

Moreover, reflected in the embrace of infinitely revisable "warranted assertions" and overweening confidence in the experimental approach to all questions of public policy is a blithe oversight of the forms of irreplaceable natural and human costs that such "experimentation" may and does entail. One can reasonably stipulate that a significant portion of "experimentation" is done today in order to relieve humanity and the global ecology of the negative consequences of previous experiments - some among which, once implemented as a remedy, can be reasonably expected to have yet unforeseen negative consequences - just as projects that are speculatively being undertaken to "relieve the human estate" will in all likelihood themselves result in further unforeseen negative consequences in one domain even as they ameliorate the human 
condition in another. ${ }^{84}$ Because all setbacks are in fact constructive from an experimental viewpoint,and all consequences that result from progress allow for further improvement, in the worldview of the democratic faithful there is little or no awareness of human and natural implications of negative costs, the limitations imposed by "path dependency," and the intractableness of tragedy. The "democratic faithful" evince an unwillingness, or inability, to see negative consequences of assumptions that underlie the embrace of material and moral "progress" as part of the democratic faith.

This reflects a wider inability to acknowledge the presence of tragedy embedded in democratic overconfidence - an acknowledgement that can make avoidance of tragic consequences more likely. ${ }^{85}$ Richard Rorty, for one, speaks of modern belief in religion and "truth" as a form of "poetry," yet is strikingly incapable of discerning the cautionary lessons from even poetry that he otherwise embraces. For example, echoing sentiments in Emerson's “American Scholar” address, Rorty contrasts the tired metaphysical philosophy of Europe with the "new metaphysic" of democracy in the New World:

Just as Mark Twain was convinced that everything bad in European life and society could be corrected by adopting American attitudes and customs which is Connecticut Yankee brought to King Arthur's Court, so Dewey was convinced that everything that was wrong with traditional European philosophy was the result of clinging to a world picture which arose within, and met the needs of, an inegalitarian society. ${ }^{86}$

This is, to say the least, a surprising understanding of Twain's novel from a professor of Comparative Literature at Stanford University. While it is true that Hank Morgan, the "Yankee," skewers aristocratic and religious traditions in medieval England, by the end 
of the novel he proves to be more brutal and murderous than the knights he ridicules. Using the technologies of the Gatling gun, modern explosives, and electricity generated from coal, he succeeds in killing thirty-thousand of Arthur's knights, and in the process defeats himself as he and his band of modernist allies succumb to the pestilence that the piled corpses create. Twain's novel hardly stands as a morality tale about the corrupt evils of Europe opposed to the decencies of America, but rather - in addition to deriding the inequalities of English aristocratic society - even more fiercely condemns the smug superiority of American optimism that refuses to see the ways that its own democratic faith both overlooks, and may itself contain, seeds of inescapable human tragedy and cruelty. In light of this oversight, Rorty's sympathy for an "Americanized humanity" is all the more alarming. ${ }^{87}$

"Democratic Faith" appropriately reflects a version of what philosopher Michael Oakeshott called "The Politics of Faith" - a form of political "faith" notable for the "absence of doubt" about itself, an unscrupulous belief "in the redemption of mankind in history and by human effort" aimed at the "perfection of mankind" and informed by a kind of "cosmic optimism." 88 Oakeshott contrasted this form of politics with "the Politics of Scepticism," a politics conducted under the assumption that humankind is not capable of its own perfection, one notable for "prudent diffidence" rather than "radical doubt," one hesitant about the claims of political rule and wary of despotism created in the name of progress or "the people."

What is striking in Oakeshott's formulation is the extent to which those who maintain the "Politics of Faith" almost unanimously attack "faith" in its religious form (such as Machiavelli and Bacon - or, by extension, Dewey and Rorty), whereas those 
whom Oakeshott identifies as maintaining "the Politics of Scepticism” include religiously "faithful" thinkers such as Augustine, Pascal, and Tocqueville. ${ }^{90}$ Whereas a pragmatic form of faith, notably "democratic faith," secures belief in an ever improving future, the "politics of skepticism" is reinforced by the initial embrace of faith in redemption beyond the wholly human or political that is in turn accompanied by insistence upon humility and circumspection. Democracy may, in the end, require faith in some form, but it remains contestable whether the "democratic faith" of pragmatism is finally the form of faith that best serves the cause and prospects of democracy. 


\section{Notes}

${ }^{1}$ John Dewey, "The Democratic Faith and Education," in Philosophy of Education (Problems of Men) (Totowa, NJ: Littlefield, Adams \& Co., 1975 [1944]), 33.

${ }^{2}$ Dewey, "Religion and Our Schools," 168.

${ }^{3}$ Wilhelm Nestle, Vom Mythos zum Logos (New York: Arno Press, 1978 [1942]). Cf. F. M. Cornford, From Religion to Philosophy: A Study in the Origins of Western Speculation (Princeton: Princeton University Press, 1991 [1912]), who finds far greater interdependence between the ancient religion and philosophy.

${ }^{4}$ See especially E. A. Burtt, The Metaphysical Foundations of Modern Science (Garden City, NY: Doubleday \& Company, Inc., 1954).

${ }^{5}$ Francis Bacon wrote that "a little or superficial knowledge of [natural] philosophy may incline the mind of man to atheism, but a further proceeding therein doth bring the mind back again to religion." Bacon, The Advancement of Learning (New York: Modern Library, 2001), 910.

${ }^{6}$ The "religiosity" of the early proponents of the scientific enterprise is explored at greater and more exhaustive length by a number of studies, all of which have been of great assistance in elaborating on this "method" of realizing "democratic faith," although none of these authors themselves draw this historical or intellectual connection. Among the most helpful have been Norman Cohn, The Pursuit of the Millennium: Revolutionary Millenarians and Mystical Anarchists of the Middle Ages (New York: Oxford University Press, 1970); Amos Funkenstein, Theology and the Scientific Imagination from the Middle Ages to the Seventeenth Century (Princeton: Princeton University Press, 1986); Eugene M. Klaaren, Religious Origins of Modern Science: Belief in Creation in Seventeenth-Century Thought (Grand Rapids, MI: Eerdman's Publishing Co., 1977); David F. Noble, The Religion of Technology: The Divinity of Man and the Spirit of Invention (New York: Knopf, 1998); Ernest Lee Tuveson, Millennium and Utopia: A Study in the Background of the Idea of Progress (Berkeley, CA: University of California Press, 1949); Charles Webster, The Great Instauration: Science, Medicine and Reform, 1626-1660 (London: Duckworth, 1975).

${ }^{7}$ Noble, The Religion of Technology, 3-100.

${ }^{8}$ Noble, The Religion of Technology, 104, 9.

${ }^{9}$ See R. G. Collingwood, The Idea of Nature (Oxford: Clarendon, 1945).

${ }^{10}$ Giordano Bruno, "The Expulsion of the Triumphant Beast," quoted in Noble, The Religion of Technology, 39-40. Bruno's suggestion that humanity comes to know the mind of God by means of "emulation of the actions of God" is within the "maker's knowledge tradition" that culminates in the thought of Francis Bacon. See Antonio Pérez-Ramos, "Bacon's Forms and the Maker's Knowledge Tradition," in The Cambridge Companion to Bacon, ed. Markku Peltonen (New York: Cambridge University Press, 1996), 99-120, and Pérez-Ramos, Francis Bacon's Idea of Science and the Maker's Knowledge Tradition (New York: Oxford University Press, 1988).

${ }^{11}$ Charles Webster, The Great Instauration, esp. 8, 15-16, 100-3, 324-335, 516; Klaaren, The Religious Origins of Modern Science, 85-126; Noble, The Religion of Technology, 43-87.

${ }_{12}$ John Milton, "Prolusions," in Complete poems and Major Prose ed. Merritt Y. Hughes (Indianapolis: Bobbs Merrill, 1957), 625.

${ }^{13}$ Pico della Mirandola, "Oration on the Dignity of Man," in The Renaissance Philosophy of Man, ed. Ernst Cassirer, Paul Oskar Kristeller, and John Herman Randall Jr. (Chicago: University of Chicago Press, 1948), 224.

${ }^{14}$ Pico della Mirandola, "Oration on the Dignity of Man," 224.

${ }^{15}$ Pico della Mirandola, "Oration on the Dignity of Man," 224-5. 
${ }^{16}$ Pico della Mirandola, "Oration on the Dignity of Man," 223.

${ }^{17}$ Pico della Mirandola, "Oration on the Dignity of Man," 225.

${ }^{18}$ Pico della Mirandola, "Oration on the Dignity of Man," 248. The first aphorism of Francis Bacon's Novum Organum similarly calls man "the servant and interpreter of Nature"; in the third aphorism he further states, "we can only command Nature by obeying her." Francis Bacon, Novum Organum, trans. Peter Urbach and John Gibson (Chicago: Open Court, 1994), 43.

${ }^{19}$ Pico della Mirandola, "Oration on the Dignity of Man," 248-9.

${ }^{20}$ Pico della Mirandola, "Oration on the Dignity of Man," 230.

${ }^{21}$ Webster, The Great Instauration, 341. The citation is to be found, for example in Francis Bacon, The Advancement of Learning, 41.

${ }^{22}$ Francis Bacon, The Advancement of Learning, 36.

${ }^{23}$ Bacon, The Advancement of Learning, 6; 39.

${ }^{24}$ Bacon, Valerius Terminus, "Of the Interpretation of Nature," in The Works of Francis Bacon, ed. James Spedding, Robert Leslie Ellis and Douglas Denon Heath, v. 3 (London: Longmans \& Co., 1870), 218.

${ }^{25}$ Bacon, Valerius Terminus, 217. The conjecture of its 1603 composition is justified in an introductory note on pp. 207-8.

${ }^{26}$ Bacon, Valerius Terminus, 217.

${ }^{27}$ Bacon, Valerius Terminus, 218.

${ }^{28}$ Bacon, The Advancement of Learning, 7.

${ }^{29}$ Bacon, The Advancement of Learning, 37.

${ }^{30}$ Bacon, Valerius Terminus, 221.

${ }^{31}$ Perez Zagorin also explores Bacon's fascination with the possibility of prolonging life and even overcoming death, by means of reversing the original Fall, in Francis Bacon (Princeton: Princeton University Press, 1998), 44-51.

${ }^{32}$ Bacon, Valerius Terminus, 223.

${ }^{33}$ Bacon, The Advancement of Learning, 56; 58; 60. Bacon is here careful to suggest that by "heavens" he means the contemplation of outer space, and "immortality" is that sort achieved by lasting achievements, such as the epics of Homer (60-1). Nevertheless, the invocation of the language of "ascent," "heaven," and "immortality" - here contrasted to "vulgar" ends of knowledge - unmistakably echoes arguments such as those by Pico, Bruno, and Bacon himself, that mankind should seek ultimately to "reinstate" his former state of immortal and even quasidivine innocence prior to the Fall.

${ }^{34}$ Bacon, "Prometheus, or the State of Man," in Lord Bacon's Essays (Boston: Little, Brown \& Co.), 391-394.

${ }^{35}$ Bacon, "Prometheus," 394.

${ }^{36}$ Bacon, "Prometheus," 395.

${ }^{37}$ Bacon, "Prometheus," 395.

${ }^{38}$ Bacon, "Prometheus," 397.

${ }^{39}$ Bacon, "Prometheus," 397, 398.

${ }^{40}$ Bacon, "Prometheus," 398.

${ }^{41}$ Bacon, "Prometheus," 395.

${ }^{42}$ Bacon, "Prometheus," 400. Bacon was confident that mankind had reached a stage at which it could overcome past errors and achieve new and transformative forms of power and dominion by means of the advancement of knowledge:

This is a thing which I cannot tell whether I may so plainly speak as truly conceive, that as all knowledge appeareth to be a plant of God's own planting, so it may seem the spreading and flourishing or at least the bearing and fructifying of this pant, by a providence of God, nay not only by a general providence but by a special prophecy, was appointed to this autumn of 
the world: for to my understanding it is not violent to the letter, and safe now after the event, so to interpret that place in the prophecy of Daniel where speaking of the latter times it is said, Many shall pass to and fro, and science shall be increased; as if the opening of the world by navigation and commerce and further discovery should meet in one time or age."

Bacon, Valerius Terminus, 221.

${ }^{43}$ Bacon, "Prometheus," 405.

${ }^{44}$ Bacon calls attention to this curious displacement by explaining that he sought not "to break the connection of things," and thus "designedly omitted the last crime of Prometheus" ("Prometheus," 404).

${ }^{45}$ Bacon, "Prometheus," 403-4.

${ }^{46}$ Bacon, "Prometheus," 404.

${ }^{47}$ Bacon, "Refutation of Philosophies," in The Philosophy of Francis Bacon, ed. Benjamin Farrington (Chicago: University of Chicago Press, 1964), 106. Thomas Hobbes - who served for a time as Bacon's personal secretary - used the phrase "Mortall God" to describe his "Leviathan." Thomas Hobbes, Leviathan, ed. Richard Tuck (New York: Cambridge University Press, 1991), ch. 17, sec. 87, p. 120.

${ }^{48}$ Markuu Peltonen has argued interestingly that Bacon should be understood as belonging to the republican tradition due to his frequent reliance on the thought of Machiavelli and his influence on James Harrington, in "Bacon's Political Philosophy," in The Cambridge Companion to Bacon, ed. Markku Peltonen (New York: Cambridge University Press, 1996), 283310. However, Zagorin rightly notes that Bacon's resemblance to republicanism stops well short of endorsing popular rule, and explores at greater length his commitment to monarchy and political secrecy, in Francis Bacon, 147-74. On Bacon's insistence on the necessity of secrecy in government affairs, see, for instance, The Advancement of Learning, 208-211.

${ }^{49}$ John Dewey, The Public and its Problems (Athens, OH: Swallow Press, 1985 [1927]), 164.

${ }^{50}$ Dewey, The Public and its Problems," 183, 184. Thus, like Whitman, Dewey recommended the role of the poet as final proselytizer of democracy, though his text would be considerably more "scientific" than Whitman likely supposed.

${ }^{51}$ Bacon, Novum Organum, I.61, p. 66. See also Zagorin, Francis Bacon, 85.

${ }^{52}$ Bacon, Valerius Terminus, 227.

${ }^{53}$ Bacon, New Atlantis, ed. Jerry Weinberger (Wheeling, IL: Harlan Davidson, 1989), 71.

${ }^{54}$ John Dewey, Reconstruction in Philosophy (Boston: Beacon Press, 1957 [1920]), 28,

38.

${ }^{55}$ Dewey, Reconstruction in Philosophy, 28-38. Bacon articulated the need for doubt (though not skepticism) in a felicitous phrase in The Advancement of Learning: "if a man will begin with certainties, he shall end in doubts; but if he will be content to begin with doubts, he shall end in certainties" (35).

${ }^{56}$ Dewey, The Public and Its Problems, 146; cf. p. 144.

${ }^{57}$ Dewey, Reconstruction in Philosophy, 28.

${ }^{58}$ One can only survey the vast and expanding recent literature on the human implications of the genome project to see this is the case. On a more sanguine projection of human transformation, see Lee M. Silver, Remaking Eden: Cloning and Beyond in a Brave New World (New York: Avon Books, 1997). For a criticism of the implications of the genome project on both religious and secular grounds, see Francis Fukuyama, Our Posthuman Future:

Consequences of the Biotechnology Revolution (New York: Farar, Strauss and Giroux, 2002), and Peter A. Lawler, Aliens in America (Wilmington, DE: ISI Books, 2002); see also David Noble, The Religion of Science, 103-228. 
${ }^{59}$ Richard Rorty, "Religious Faith, Intellectual Responsibility and Romance," in Philosophy and Social Hope (New York: Penguin Books, 1999), 162.

${ }^{60}$ See, for example, Rorty, "A World Without Substances or Essences," in Philosophy and Social Hope, 50; and "Heidegger, Contingency and Pragmatism" in Essays on Heidegger and Others: Philosophical Papers Volume 2 (New York: Cambridge University Press, 1991), 27.

${ }^{61}$ Rorty, "Religious Faith, Intellectual Responsibility and Romance," 161.

${ }^{62}$ Rorty, Contingency, Irony and Solidarity (New York: Cambridge University Press, 1989), esp. 73-95. For a criticism of Rorty's belief in "self-creation" that points out the ways that language is not easily thrown off or wholly transformed in the manner that Rorty suggests, see Sheldon S. Wolin, "Democracy in the Discourse of Postmodernism," Social Research 57 (Spring, 1990), 21-26.

${ }^{63}$ For an insightful reflection on Bacon's own scientific and political faith, and its continued if less sanguine adherence in contemporary times, see Howard B. White's elegant study, Peace Among the Willows: The Political Philosophy of Francis Bacon (The Hague: Martinus Nijhoff, 1968), esp. ch. 1 ("Political Faith and Utopian Thought"). See also Jerry Weinberger, Science, Faith, and Politics: Francis Bacon and the Utopian Roots of the Modern Age (Ithaca: Cornell University Press, 1985).

${ }^{64}$ The Scientific Spirit and Democratic Faith (New York: King's Crown Press, 1944).

${ }^{65}$ Edward C. Lindeman, "Introduction," The Scientific Spirit and Democratic Faith, ix.

${ }^{66}$ Lindeman, "Introduction," xi.

${ }^{67}$ Lindeman, "Introduction," xi.

${ }^{68}$ Lindeman, "Introduction," xi.

${ }^{69}$ Horace M. Kallen, "Freedom and Authoritarianism in Religion," in The Scientific Spirit and Democratic Faith, 3.

${ }^{70}$ Kallen, "Freedom and Authoritarianism in Religion," 3.

${ }^{71}$ Kallen, "Freedom and Authoritarianism in Religion," 10; see also p. 6. In this context, Kallen is discussing several works by then prominent Catholic thinkers, and comparing the arguments to those of Hitler in Mein Kampf (7-10).

${ }^{72}$ Alfred Mirsky, "The Democratic Responsibilities of Science," in The Scientific Spirit and Democratic Faith, 58.

${ }^{73}$ Mirsky, "The Democratic Responsibilities of Science," 59.

${ }^{74}$ Mirsky, "The Democratic Responsibilities of Science," 60, 61.

${ }^{75}$ Richard M. Brickner, "The Democratic Responsibilities of Science," The Scientific Spirit and Democratic Faith, 63.

${ }^{76}$ Brickner, "The Democratic Responsibilities of Science," 63.

${ }^{77}$ Brickner, "The Democratic Responsibilities of Science," 64.

${ }^{78}$ Mirsky, "The Democratic Responsibilities of Science," 60.

${ }^{79}$ Rorty, Achieving Our Country, 142, n. 12.

${ }^{80}$ For examples of confidence in various technologies for democratic ends, see John Dewey, A Common Faith, 49; Benjamin R. Barber, Strong Democracy: Participatory Politics for a New Age (Berkeley: University of California Press, 1984), 273-276.

While few thinkers have the unbridled enthusiasm of Marshall McLuhan in the 1960's, one discerns that the "democratic faith" lists closer to his side of his optimism than on the side of cautionary restraint:

Our new electric technology that extends our senses and nerves in a global embrace has large implications for the future of language. Electric technology does not need words any more than the digital computer needs numbers. Electricity points the way to an extension of the process of consciousness itself, on a world scale, and without any verbalization whatsoever.... The computer, in short, promises by technology a Pentacostal condition of universal understanding 
and unity. The next logical step would seem to be, not to translate, but to by-pass languages in favor of a general cosmic consciousness which might be very like the collective unconsciousness dreamt of by Bergson. The condition of "weightlessness," that biologists say promises a physical immortality, may be paralleled by the condition of speechlessness that could confer a perpetuity of collective harmony and peace.

Marshall McLuhan, Understanding Media: The Extensions of Man (New York: McGraw Hill, 1964), 80.

McLuhan's invocation of "cosmic consciousness" alerts one to the relationship of his ambitions to those of Walt Whitman's friend and biographer, Richard Burke, whose book Cosmic Consciousness argued that humans (including Whitman, along with such figures as Christ, Buddha, and Emerson) were undergoing an evolution in which consciousness was becoming universally perceptible and shared. Burke's book, in turn, was a central inspiration to Edward Bellamy's 1899 novel Looking Backwards which portrayed a utopian American future aided, in significant part, by technological advances such as a device that resembles the modern radio.

${ }^{81}$ Dewey, Reconstruction in Philosophy (New York: New American Library, 1950 [1920]), 46

${ }^{82}$ Dewey, Reconstruction in Philosophy, 48; emphasis mine.

${ }^{83}$ Indeed, David Fott has noted the incoherence of Dewey's faith in the scientific method itself: "when [Dewey] says he is willing to put his faith in science to the test, he mentions an experimental test. If science is to test science, he is obviously begging the question." David Fott, John Dewey: America's Philosopher of Democracy (Lanham, MD: Rowman \& Littlefield, 1998), 148. See also the discussion of the practical political failings of Dewey's pragmatism in John Patrick Diggins, The Promise of Pragmatism (Chicago: University of Chicago Press, 1994), chs. 4-6.

${ }^{84}$ This is true not only in the world of scientific experimentation, but the political experimentation and application as well. Consider an example from current affairs: contemporary advocates for "reform" to the campaign finance system almost always overlook the fact that current abuses are the result of previous, much-celebrated reforms that were themselves reforms of previous reforms. Recognizing this fact should not permit an overconfidence in people's ability to predict unintended consequences. Nevertheless, a "skeptical" eye toward experimental skepticism can make one cognizant, in the first instance, of the likelihood of inescapable costs that will likely result, and thereby make initial contemplation of such costs both possible and obligatory. For example, see Henry Jones Ford's remarkably prescient predictions of 1909 about the likely unintended negative consequences resulting from the introduction of the direct primary. Henry Jones Ford, "The Direct Primary," North American Review 190 (July, 1909): 189-205. For a thoughtful and sobering assessment of the current reform effort, see David S. Broder, "Now the Unintended Consequences," Washington Post (February 15, 2002), A33.

It is necessary to note, of course, this and other efforts at democratic reform take place within the context of a larger "experiment" in self-governance, the Constitutional system devised by the Founders in 1787. While there is widespread disagreement over whether the Constitution is in essence "democratic," whether it contains internal inconsistencies, or whether it contains an inherently "anti-democratic" core is the subject of profound debate. For arguments for the antidemocratic inclinations of the Constitution, see Sheldon S. Wolin, The Presence of the Past: Essays on the State and the Constitution (Baltimore: The Johns Hopkins University Press, 1989), esp. chs. 5 and 10, and Wilson Carey McWilliams, "Democracy and the Citizen: Community, Dignity, and the Crisis of Contemporary Politics in America," in How Democratic is the Constitution?, ed. Robert A. Goldwin and William A. Schambra (Washington, D.C.: American Enterprise Institute, 1980). For arguments that emphasize the Constitution's formalism and its 
limitations on majoritarianism, and thus see it as importantly, but not thoroughly, democratic, see (on the liberal/left) Christopher L. Eisgruber, Constitutional Self-Government (Cambridge, MA: Harvard University Press, 2001), and (on the liberal/right), Harvey C. Mansfield Jr., America's Constitutional Soul (Baltimore: The Johns Hopkins University Press, 1991). Both these arguments reflect an underlying agreement that the Constitutional system establishes significant limitations on widespread civic participation, and thus, by extension, limits the plausibility of the realization of the "tranformative" democratic polity fondly wished by the "democratic faithful."

For an insightful essay that suggests the limited understanding of "experiment" afforded by the American Constitutional order and historical experience, see Wilfred M. McClay, "Is America an Experiment?" in Vital Remnants: America's Founding and the Western Tradition, ed. Gary L. Gregg II (Wilmington, DE: ISI Books, 199): 1-32.

${ }^{85}$ On the tragic consequences of human over-confidence - particularly democratic and even "pragmatic" optimism - as portrayed in ancient theater, see J. Peter Euben, "Antigone and the Language of Politics" and "Oedipean Complexities and Political Science: Tragedy and the Search for Knowledge," in Corrupting Youth: Political Education, Democratic Culture, and Political Theory (Princeton: Princeton University Press, 1997), 139-201, and Charles Segal, "Sophocles' Praise of Man and the Conflicts of the Antigone," in Sophocles (Edited by Thomas Woodard. Englewood Cliffs, N.J., 1966).

${ }^{86}$ Richard Rorty, "Truth Without Correspondence to Reality," in Philosophy and Social Hope, 29.

${ }^{87}$ Richard Rorty, "Religious Faith, Intellectual Responsibility and Romance," in Philosophy and Social Hope, 163. See also "Justice as Larger Loyalty," in Cosmopolitics: Thinking and Feeling Beyond the Nation, ed. Pheng Cheah and Bruce Robbins (Minneapolis: University of Minnesota Press, 1998), esp. 56-7.

${ }^{88}$ Michael Oakeshott, The Politics of Faith and the Politics of Scepticism (New Haven: Yale University Press, 1996), 26, 55, 23. Oakeshott attributes the origins of the "politics of faith" to Francis Bacon (52-7), much as Dewey recognizes Bacon's formative influence in his own thought in Reconstruction in Philosophy, and Rorty as a fundamental source in, among other places, Consequences of Pragmatism (Essays: 1972-1980) (Minneapolis: University of Minnesota Press, 1982), xvii.

${ }^{89}$ Oakeshott, The Politics of Faith and the Politics of Scepticism, 30-38. Oakeshott refers briefly to a contemporary faith in democracy as one form of "the politics of faith," though he does not consider its particular manifestation or implications at any length (pp. 130-2).

${ }^{90}$ Oakeshott composes an "ill-assorted gallery" of the "politically skeptical," which in addition to including the likes of Augustine and Pascal, also includes Spinoza, Hobbes, Bentham and the Federalists. Oakeshott, The Politics of Faith and the Politics of Scepticism, 80-1, 129. 